\title{
The Use of Qualitative Indicators in Banking Rating Systems
}

\author{
Martin Svítil \\ Soukromá vysoká škola ekonomická Znojmo \\ Loucká 656/21, 66902 Znojmo \\ E-mail: svitil.martin@svse.cz
}

\begin{abstract}
The article compares internal rating systems of three banks from the German-speaking region, continuing with last year's research. In this paper a detailed analysis of qualitative indicators (soft - facts) is made. These qualitative indicators, as one of the two main components of banking rating systems have the wage of between $30 \%$ and $50 \%$ of the overall rating score. This makes this part of rating certainly important enough to be further researched. The research is focused on the rating of business entities, more precisely the corporate, (especially limited liability companies or joint-stock companies). It does not deal with the rating of natural persons or non-profit organizations, municipalities etc. The procedure of collecting empirical data as well as data from relevant literature, their assessment according to the criteria of verifiability and relevance and the application of the induction method was used and a generalization of conclusions was subsequently made. The goal of this research was to find out if the structure of used qualitative factors (soft-facts) is similar or even the same across the rating systems included in the comparison and what weights of individual factors are used. The result of the research shows that two categories of qualitative indicators (soft - facts) are present in all considered rating systems: (i) quality of company's management and / or strategy and (ii) market on which the bank client operates. (iii) Accounting or related indicators like information system or audit quality also play a significant role in rating systems. On the other hand, the use of the factor (iv) relationship with the bank (or similar) is quite different across the rating systems included in the research. The number and structure of guidance questions that help riskmanagement analysts determine indicator values also differ. In one case, there is an extensive catalog of questions with a standardized set of responses. In other cases, the number of questions is lower and each one has its specific variation of the predefined answers the analyst selects from.
\end{abstract}

Keywords: rating, risk management, soft-facts, qualitative factors

JEL code: G24

\section{Introduction}

In the last year's and current works (Svítil, 2017a, Svítil, 2017b, Svítil, 2018) the comparison of three internal rating systems compatible with IRB Approach for Basel II was made. The result of the research showed, that the structures of compared bank's internal rating systems are very similar, based mainly on integration of 
"hard-facts" rating, based on quantitative indicators, and "soft-facts" rating, based on qualitative indicators.

To continue the research, the focus was set on the qualitative factors (soft - facts), which seems to be much less detailed in the recent literature (see below). Comparable data could be found in just a few works, and in all cases only a single rating system was mentioned. If it was worthwhile (Belás, Cipovová (2011), Kavan (2017) and Radojevic, Suknovic (2008), for details see below), this data were added to the comparison in this paper. However, the main sources are three internal rating systems used currently and / or in the recent past by three banks or banking groups originating from the German-speaking economic environment and regions. All the mentioned banks use their rating tools to estimate the credit risk of their clients, expressed in the PD (probability of Default).

This article is an extended and more detailed version of the conference paper (Svitil 2018). Especially the part 3.2 Qualitative indicators (soft - facts) was substantially extended by a more detailed structure of the indicators and a list of guidance questions in the preparation of the rating.

The aim of this paper was to find out to what extent is the structure of used qualitative factors (soft- facts) similar or even the same across the particular rating systems and what weights of individual factors are used for calculations.

\section{Review of Literature}

Belás and Cipovová (2011) analyze the requirements for rating models of banks in relation to financial performance and compare them to selected credit scoring and bankruptcy models. In their work, there is just one real model (used by existing bank) mentioned. The conclusion of the research showed that "Bankruptcy and credit scoring models produce results that aren't quality sufficient for credit decisions. The final decision about proposal to qualified loans should be based on expert estimates of credit analyst, which should assess whether the company is able to withstand the temperature rise or it's threatened by insolvency on the basis of detailed financial analysis." (Belás, Cipovová (2011), p.119). This conclusion confirms that it is meaningful and important to examine the qualitative elements of rating systems, which is the essence of this article.

Grunert, Norden and Weber (2005) in their work came from a similar background as the data in this text: they surveyed data from four major German banks. Their conclusion is unambiguous: the combined use of financial and non-financial factors leads to a significantly more accurate default prediction than the single use of either financial or non-financial factors. But they have been limited by the availability of data.

Another German writing author Richard Guserl (2014) emphasizes the importance of communication between the bank and the rated client, especially the role of the chief financial officer (CFO) of the rated company. He also mentions the warning 
signals such as rumors in the market, late payments, overdraft of credit lines, defaults on other loans, inadequate capitalization, or even criminal proceedings etc. For the respective weight of qualitative and quantitative indicators (hard- and soft - facts) on the final rating, Guserl states about $40 \%$ - $50 \%$ weight for soft-facts for larger companies (which also corresponds to data available for this paper, see below) and higher weight of soft-facts for smaller companies - even $65 \%$ to $70 \%$. The sources / data used for this paper cannot confirm (or refuse) these particular numbers, but they unambiguously confirm the increase in the importance of softfacts in the rating of smaller companies.

Hofmann (2006) also states the assessment of the subjective factors of a company like quality of management, product and competitive situation, human resources, or organization as an important part of the creation of the rating. The significance of the subjective assessment (soft-facts) differed according to his research at the monitored banks, with an average weight of $27,8 \%$. He further states that banks are not subject to any rules in regards to assigning respective importance to subjective and objective factors.

The research conducted by Fracassi, Petry and Tate (2016) examined the influence of the analyst's subjective judgment on the outcome of the rating, and although the article deals more with credit rating agencies (CRA) than banks, its outcome is worth mentioning: "We find that significant variation in credit ratings can be explained by differences in the dispositional optimism of the analysts covering the firm. (...) Our results suggest that some firms can face more frictions in raising capital simply because they are covered by less able credit analysts. Perhaps of more significance, our results suggest that long-term relationships between firms and the analysts who rate their debt issues can lead to inflated ratings and costs of capital that are too low." (Fracassi, Petry, Tate (2016), p. 535). This article briefly focuses on attempts to minimize possible negative impacts of subjective assessment by one person in Part 3.3.

The importance of qualitative factors for rating is also mentioned by other authors, like Morrow (1998), or Crouhy, Galai, Mark (2001): "The rating process includes quantitative, qualitative and legal analyses. (...) The qualitative analysis is concerned with the quality of management, and includes a thorough review of the firm's competitiveness within its industry as well as the expected growth of the industry and its vulnerability to technological changes, regulatory changes and labor relations." (Crouhy, Galai, Mark (2001), p. 51).

\section{Data and Methodology}

For comparison, documentation of three rating systems used by three different banks (banking groups) from the German-speaking environment was available. Since some of these documents are confidential and have not been granted full disclosure, the results of the investigations are limited in some respects. It is also not possible to publish the names of the mentioned banks (banking groups). The 
data is anonymized accordingly in order not to affect its value for the research. These three banking institutions and their rating systems are listed under A, B and C. As far as known, these models are also used in the present time, either completely without modification or with minor changes.

Data from available literature was also used for comparison: Belás, Cipovová (2011), Kavan (2017) and Radojevic, Suknovic (2008). The first mentioned source concerns a real (anonymous) bank operating in Central Europe, the second one is a leasing company owned by an Austrian bank. The last mentioned source is just a proposal (not yet used in practice), but interesting enough to be included in the comparison. These three rating systems are listed under $\mathbf{D}, \mathbf{E}$ and $\mathbf{F}$, where $F$ is the unused proposal.

The research is focused on the rating of business entities, more precisely corporate, (especially limited liability companies or joint-stock companies). It does not deal with rating of natural persons or non-profit organizations, municipalities etc. Excluded are also the banks, insurance companies, leasing companies etc. For all these entities the examined banks $(A, B, C)$ have different special modules in their rating systems.

The procedure of collecting empirical data, its assessment according to the criteria of verifiability and relevance, and the application of the induction method was used and a generalization of conclusions was subsequently made. Due to the nature and extent of the available data, the use of quantitative analysis was not possible.

\section{Results and Discussion}

\subsection{The Weight of the Qualitative Factors (Soft-Facts) in the Rating Systems}

For better understanding of the rating system as a whole, its basic structure must be described briefly. This structure (as shown in the Figure 1) is quite similar for all of the mentioned rating systems (except rating system $E$ in some respects), just the names used for particular steps are different. At the same time, we pay attention to the weight qualitative criteria (soft - fact) are assigned in the rating result.

All three compared rating tools first produce the part of the rating, based on clients' financial statements (financial data). After possible other inputs like sector data, budgets etc., the financial statement rating becomes quantitative or hard-facts (HF) rating, as one of the two main sources for the final result. The second source is the qualitative or soft-facts (SF) rating, based on qualitative criteria (see below). 
Figure 1 The Basic Structure of the Rating Systems

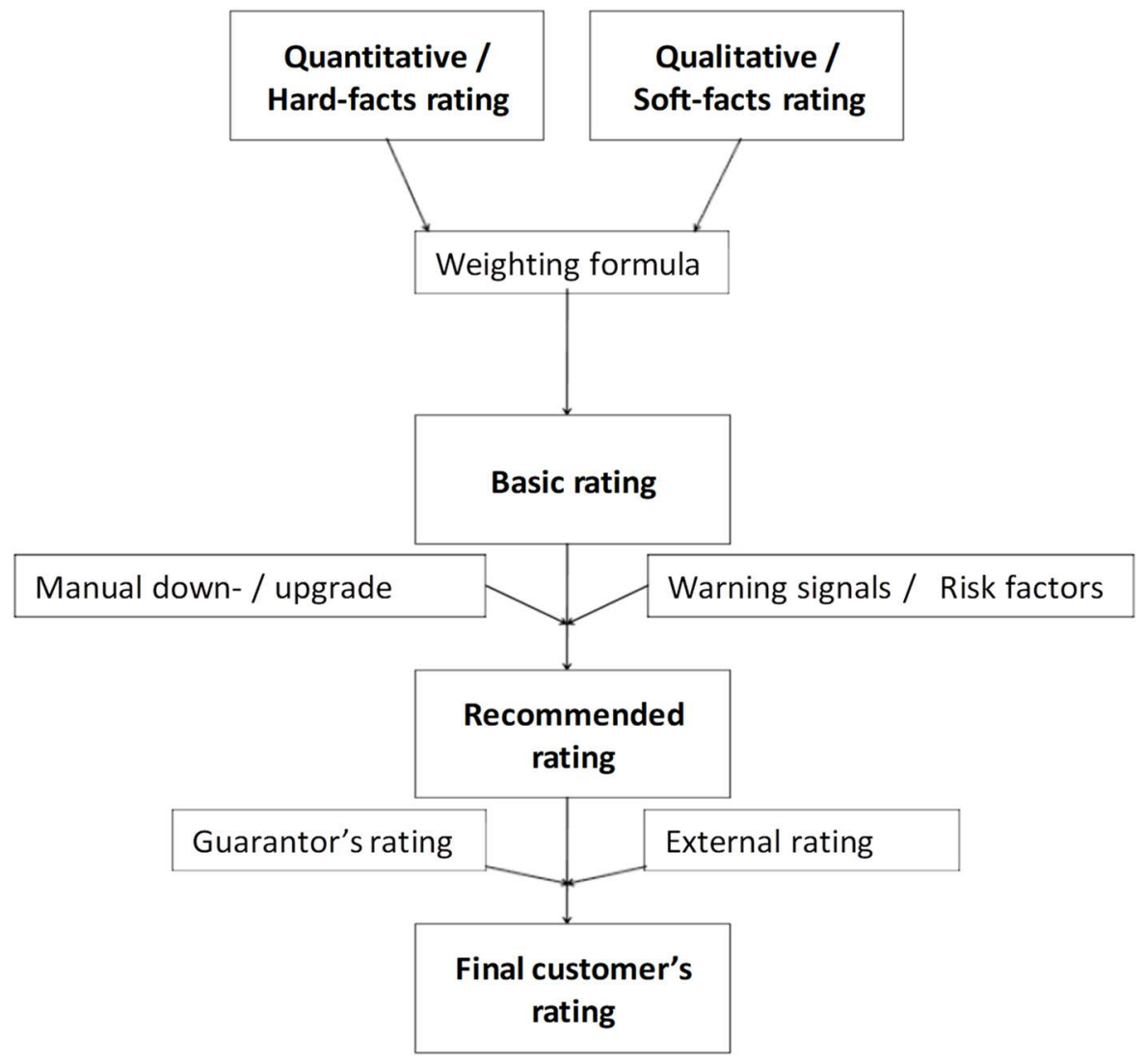

Source: Author by using banks " $A$ ", "B" and " $C$ " rating manuals

In the next stage, the hard-facts rating and the soft-facts rating are integrated together, according to a given weighting formula. This formula gives the weight (meaning) of quantitative and qualitative factors on the rating result. In all the compared rating tools, the quantitative factors (hard-facts) are more important (they enter the calculation with higher weight). Please do not confuse this highlevel formula (HF to SF) with the importance of individual qualitative factors for the soft - facts rating, as discussed below.

At bank A, the hard - facts and soft - facts ratings are weighted at a fixed ratio of $2: 1$. In addition, soft - facts cannot improve the financial statement rating by more than two grades (there are 8 grades total), whereas downgrading is unlimited.

At bank B the weight is fixed too, at ratio $60 \%$ (HF) to $40 \%$ (SF). In the contrary of the bank A system, the up- or downgrading by soft-facts is not limited in any way.

The bank's C rating system uses more advanced approach, where the weight is dependent on operating performance (revenues), as the Table 1 shows: 
Table 1 Bank C Weight of Quantitative (Hard-Facts) and Qualitative (Soft-Facts) Indicators

\begin{tabular}{lcc}
\hline \multirow{2}{*}{$\begin{array}{c}\text { Revenues as in income } \\
\text { statement }\end{array}$} & \multicolumn{2}{c}{ Weight } \\
\cline { 2 - 3 } & Hard Facts & Soft Facts \\
\hline \hline < EUR 1,1 Mio. & $50 \%$ & $50 \%$ \\
\hline EUR 1,1 - 7,3 Mio. & $60 \%$ & $40 \%$ \\
\hline EUR 7,3 - 21,8 Mio. & $62 \%$ & $38 \%$ \\
\hline EUR 21,8-75 Mio. & $65 \%$ & $35 \%$ \\
\hline > EUR 75 Mio. & $67 \%$ & $33 \%$ \\
\hline
\end{tabular}

Source: Bank " $C$ " rating manual

As the operating performance increases, the weighting of the qualitative factors (soft-facts) for the final rating result decreases. Firstly, this is because the quality of balance sheets usually increases with the size of the company. Secondly, it is because the creditworthiness of small businesses is often very much related to the person of the entrepreneur. Smaller companies are more sensitive to one person's mistakes or loss (like death of the owner / CEO in one person), and their processes (like accounting) are usually less intensively checked by internal and external audits etc.

It is also worth mentioning that for small companies with revenues of up to EUR 1,1 million, the Bank $C$ system is the only one from all compared systems that gives the same weight to both quantitative and qualitative factors.

Bank D (as mentioned in Belás, Cipovová, 2011) used the weight 43,5\% for soft facts, later changed to $30 \%$. As (Belás, Cipovová, 2011, p. 111) say: "(...) our cooperating bank has changed the ratio of qualitative and quantitative criteria in rating model used by RFB from the original ratio of $43,5: 56,5 \%$ to $30: 70 \%$, as the impact of the current crisis. There are frequent cases, where the client with good performance is granted with higher risk level just because of changes in aggregate indicators of the industry, in which the company operates. This phenomenon is quite common issue in World's banking practice. The clear disadvantage of this approach is sweeping behavior towards the clients and pro-cyclical approach of credit risk management (low rate of individualization of loan products)."

Rating system E mentioned by Kavan (2017) uses a different approach: the qualitative factors themselves do not create a soft - facts rating, they can merely change (up- or downgrade) the hard - facts component of the rating. The system uses six groups of qualitative factors (see below for details), every group can change the final rating at most by 0,5 degrees up or down, the total possible upgrade by soft - facts is limited to 1 degree, while the total downgrade is not limited (the final rating has the range 1 to 5 degrees). Note: Originally, the 
ownership structure and management criteria are formally grouped into one category, but for better comparability with other systems, I've divided them into two categories. Off course, the weights and therefore the influence on the final rating was retained.

Radojevic and Suknovic (2008) use in their paper a rating model (designated as rating system F) with fixed weights of $60 \%$ (HF) to $40 \%$ (SF), with no limits for up- or downgrade.

Using the weights (as mentioned above), the hard-facts rating and the soft-facts rating result together in a basic or automated rating. Such credit rating is then manually reviewed for possible manual down- or (in some cases) upgrading.

Next to the possible manual downgrade, all the banks use a fixed list of warning signals or risk factors. If one or more of them appear in the client assessment, the rating must be downgraded in an appropriate manner.

After the down- or upgrade or after non-use of this possibility (which is the most common case), the basic rating becomes the client's rating or recommended rating, which can be (or even must be under some circumstances) modified by other guarantor's rating or external rating, if existing. The banks use exact and similar-to-each-other rules, at what circumstances the rating of the guarantor or the external rating (usually made from one of the big rating agencies like Moody's or S\&P) must be used.

When the last step (guarantor's rating or external rating) is made or skipped, the rating becomes overruled rating or final customer's rating.

\subsection{Qualitative Indicators (Soft-Facts)}

Each of the monitored banks or financial institutions uses their own range of indicators. Whilst there are some generally accepted methods that can be used as a starting point for assessing quantitative indicators (hard-facts, like e.g. bankruptcy models), for soft-facts there are none. That's the reason why it is interesting to compare what indicators the individual banks have chosen and how their methods for calculating soft-facts differ.

Technically, in all cases, the process involves filling in a prepared form (questionnaire) in the rating software, either in the form of a direct selection on a given scale for individual factors or by answering questions from which the system itself calculates the result.

In all the banks, the qualitative indicators are grouped into several aggregated categories (topics). In some cases, these aggregated high - level categories are further broken down into more detailed questions (for details see below).

The following Tables 2 and 3 show the categories (topics) as used by particular banks. Banks $A, B$ and $C$ were the primary subjects of this research, while data on $D, E$ and $F$ rating systems from other sources (see above) serves for comparison. 
Table 2 Qualitative Indicators (Soft-Facts) - Part 1

\begin{tabular}{|c|c|c|c|c|c|}
\hline \multicolumn{2}{|l|}{ Rating A } & \multicolumn{2}{|l|}{ Rating B } & \multicolumn{2}{|l|}{ Rating C } \\
\hline Management & $15 \%$ & Strategy & & Management & \\
\hline & & & $17 \%$ & & $30 \%$ \\
\hline $\begin{array}{l}\text { Internal organisation } \\
\text { (Accounting, } \\
\text { Technology) }\end{array}$ & $15 \%$ & & & Accounting & \\
\hline & & & & $\begin{array}{l}\text { Qualifications of } \\
\text { employees / } \\
\text { Technology } \\
\end{array}$ & $10 \%$ \\
\hline Market / Industry & $15 \%$ & $\begin{array}{l}\text { Influence / Market } \\
\text { position }\end{array}$ & $27 \%$ & $\begin{array}{l}\text { Market incl. supplier } \\
\text { and customer } \\
\text { structure }\end{array}$ & $30 \%$ \\
\hline $\begin{array}{l}\text { Relationship with the } \\
\text { bank }\end{array}$ & $40 \%$ & - & & $\begin{array}{l}\text { Relationship with } \\
\text { bank }\end{array}$ & $10 \%$ \\
\hline $\begin{array}{l}\text { Miscellaneous (Age of } \\
\text { the company, } \\
\text { Location...) }\end{array}$ & $15 \%$ & $\begin{array}{l}\text { Economic situation } \\
\text { (general, influence on } \\
\text { the company) }\end{array}$ & $27 \%$ & & \\
\hline & & $\begin{array}{l}\text { Divergence from } \\
\text { planning in last } 3 \mathrm{yrs} .\end{array}$ & $15 \%$ & & \\
\hline & & $\begin{array}{l}\text { Business expectations } \\
\text { incl. bank's view }\end{array}$ & $15 \%$ & & \\
\hline
\end{tabular}

Note: The weights can be rounded.

Source: Author by using banks " $A$ ", "B" and " $C$ " rating manuals

In the bank A rating manual, the soft-fact rating is called "key account manager's soft-fact rating" and the key account manager "relies on available verbal descriptions" (Bank "A" rating manual, 2011).

In rating system of bank $\mathbf{A}$, the criteria are structured along the following five categories (see below). For every category except the Relationship with the bank, a list of detailed questions is prepared for the analyst. The answers are ranked on a positive / neutral / negative / strongly negative scale, but not for every category / question all the answers are available (see below). As an aid to analysts, examples of possible situations and responses are given in the relevant system manual. These are, however, just examples that serve to better understand and appreciate, not a definitive list of all possibilities. 


\section{- MANAGEMENT:}

\section{Successor:}

Neutral $=$ The potential successor's qualification and experience suggest no change in the situation of the respective enterprise.

Negative $=$ The entrepreneur's age and/or health make a succession a relevant issue. The potential successor's qualification and experience suggest a deterioration in the situation of the respective enterprise.

Strongly negative $=$ The enterprise could not be continued in case of (unexpected) loss of the entrepreneur.

Not applicable $=$ Succession is of no relevance due to size of the enterprise.

\section{Qualification of Management:}

Positive $=$ Members of the management team are highly qualified and experienced.

Negative $=$ Competence and experience of managers are impossible or difficult to measure objectively. / Frequent changes in management, high fluctuation in key positions. / Dominant leadership.

Strongly negative = Obvious management mistakes. / Strong personal differences. / Significant staff fluctuation.

\section{Privacy of management:}

Neutral $=$ No negative information about private life of decision-makers.

Negative $=$ Difficult family (e.g. divorce), health or financial situation or problems with alcohol, gambling etc.

Strongly negative = Shareholders' extreme lifestyle consistently undermines the enterprise.

Not applicable $=$ The personal sphere of managers is not relevant due to the enterprise's size / structure. (e.g. all key decision are made on four-eyes principle).

\section{Ability to innovate:}

Positive $=$ The organisation itself is proactive in driving industry trends.

Neutral = Corporate appropriately responses in terms of continuous product development, which allows the organisation to adapt to changing markets.

Negative $=$ The enterprise is unable to anticipate market trends and to respond quickly by launching new products. 


\section{- INTERNAL ORGANISATION OF COMPANY:}

\section{Accounting:}

Positive $=$ Financial statements with unqualified auditor's report, notes and management report as required. There is a detailed annual plan (corporate performance, fin. statements etc.).

Neutral = Signed financial statements incl. notes and management report as required. There is an annual plan.

Negative $=$ Accounting records are not signed by managing director. / Inadequate debt collection. / Records are provisional and not current.

Strongly negative $=$ Records are not sufficient, full of mistakes and inconclusive. / No records exist.

\section{Organisational structure:}

Positive $=$ Clear competences and tasks, consistent implementation of corporate policy. / Effective management system (e.g. ISO 9000 certification in place). / Flat hierarchies.

Neutral = Basic quality management systems in place. / Information systems of an average standard.

Negative $=$ Frequent uncertainty on tasks and competences, existence of considerable gaps. / Very long decision-making processes, slow responses to changes.

\section{Technological standard:}

Positive = Equipment, machinery and/or IT are up-to-date or even state-of-the-art. / Efficient use of new technologies.

Neutral = Equipment, machinery and/or IT meet the standard required to be competitive.

Negative $=$ Equipment, machinery and/or IT are clumsy, incompatible or outdated.

\section{External information policy:}

Positive = Competent, accessible contact persons. / Financial statements and other important information are provided promptly and automatically.

Neutral = Information is available upon request.

Negative = Inadequate reporting systems. / Information is available with significant (unjustified) time delay. 


\section{- MARKET / INDUSTRY:}

\section{Dependency on suppliers:}

Positive $=$ No dependency because of broad supplier base. / Even key suppliers are easily replaceable.

Neutral = Low dependency on single suppliers. / Average dependency compared to the industry standard. / Key suppliers can be replaced relatively easily.

Negative $=$ The market is only made up of a few suppliers so that continuity of production could be affected by loss of one single supplier. / Regional concentration of suppliers in high-risk zones (e.g. critical countries).

Strongly negative $=$ The market consists of few providers only (monopoly or quasi-monopoly). / Insolvency or loss of a supplier would stop the production or interrupt deliveries to retail companies.

\section{Dependency on customers:}

Positive $=$ No dependency because of broad customer base. / No regional customer concentration in high-risk zones.

Neutral $=$ Minor dependency. There is a very low dependency on a single customer.

Negative $=$ High customer concentration. Loss or insolvency of even one customer would have a strong negative impact on the company's financial situation.

Strongly negative $=$ The price is dictated by the buyer. / Insolvency or loss of a customer implies a going-concern risk for the enterprise.

\section{Sensitivity to economic cycles:}

Positive $=$ Low dependency on economic cycles. / Products or services are staple goods.

Neutral = Average dependency economic cycles.

Negative $=$ High dependency on economic cycles. / Risk of low spending of consumers at times of slow economic activity (luxury goods...) or replacement by other products.

\section{Market position:}

Positive $=$ No or hardly any competitors (only/dominant provider in the relevant market). / Company holds a strong competitive position.

Neutral = Low to average competition. / Perfect competition.

Negative $=$ High competition . 
Strongly negative $=$ Very high competitive pressure. / Tendency towards market concentration. / Price wars.

\section{Product and Development:}

Positive $=$ High-quality, fast selling products/services. / "Cash cows". / No need for big changes in product range.

Neutral = Good, normal/average-quality products. / No weaknesses in the product mix.

Negative $=$ The product lifecycle at the end. / The company is forced to change or modify its product range. / Products or services are subject to fast changing trends.

\section{Expected market development:}

Positive $=$ Growth market.

Neutral = Stable (stagnant) market.

Negative $=$ Declining market.

\section{Capacity and its utilization:}

Positive $=($ Nearly) full activity level (machines, plants, workers).

Neutral = Adequate activity level, reserves exist.

Negative = Idle capacities, weak order status, make-to-inventory production.

- RELATIONSHIP WITH THE BANK: (no detailed questions, only the ranking)

\section{- MISCELLANEOUS:}

\section{Age of the company:}

Neutral $=$ Established enterprise (more than five years on the market).

Negative $=$ Start-up or less than five years on the market.

\section{Credit standing of entrepreneur / shareholders:}

Positive $=$ Entrepreneur's or shareholder's private assets would be available as collateral if required.

Neutral = Limited liability / No private assets available as collateral.

\section{Location / region:}

Positive $=$ Very good location, good transport facilities.

Neutral = Average location, acceptable transport facilities.

Negative $=$ Location unsuitable for the type of business activity (e.g. lack of space for extension...), inadequate transport facilities. 
Other: (no detailed questions, only the ranking)

Bank B does not use further structuring of the categories, but similarly to bank C (see below), they employ the questions (one or two for every category), which should help the analyst to assess the company properly. Answers are predefined, individual for each question.

\section{Strategy:}

- Does the bank regard the company's strategy as comprehensible and realizable?

The available answers are:

- Yes, comprehensible and realizable.

- Yes, comprehensible, but only partially achievable.

- No, not completely comprehensible.

- Unknown.

\section{Divergence from planning:}

- Has there been a significant negative divergence between company's expectations / planning and the actual results at least once within the last three years?

- No.

- Yes, the company is responsible for it (internal effects).

- Yes, but the company is not responsible (external effects.

- Yes, due to internal and external reasons.

- Unknown.

\section{Business expectations:}

- Describe the company's business expectations for the next one to two years:

- Very positive (strong/above average growth or stability at an already high level).

- Positive (growth or stability at a high level).

- Neutral (constant sales at an acceptable level).

- Negative (decreasing sales or constant development at a low level).

- Very negative (strongly declining sales or constant development at a very low level).

- Unknown.

- Does the bank share the company's business expectations for the next one to two years?

- Yes.

- No, the bank estimates the future business development of the company to be better than the company's expectations. 
- No, the bank estimates the future business development of the company to be worse than the company's expectations.

- Unknown.

\section{Market influence:}

- Is the company able to co-determine / decisively influence the market development due to its position in its main markets?

- The company is able to co-determine / influence the market development in all main business segments.

- The company is able to co-determine / influence the market development in at least one main business segment.

- No, the company is not able to co-determine / influence the market development in any business segment.

- Unknown.

\section{Economic situation:}

- How do fluctuations in the general economy affect the industry(-ies) / end-user markets of the company's main segments?

- Hardly and dependency on general economy in all main business segments.

- Partially dependent on general economy.

- Strong/high dependency on general economy.

- Very strong/very high dependency on general economy.

Bank C also uses predefined sets of questions, with between five and ten questions on each topic (category). In this case, the analyst answers the particular questions directly to the software. The analyst himself does not directly decide how to rate the whole category (e.g. Management), but the system itself calculates the overall assessment based on individual analyst responses. At the end, the result of the individual categories as well as the whole soft-rating is showed by the system. This allows each question to have its own range of answers.

For the topic Management the questions and answers are the following:

- What education does the entrepreneur / CEO have?

- University degree

- High-school or similar

- Vocational school

- None

- How much experience does the entrepreneur / CEO have?

- More than 15 years

- 6-15 years

- 1-5 years

- less than 1 year 
- Has the entrepreneur / CEO ever been insolvent?

- Yes

- No

- What is the fluctuation of the most important employees incl. management?

- Low

- Medium

- High

- What is the age of the entrepreneur?

- Less than 40 years

- 40 - 55 years

- More than 55 years

- Is the succession secured? How much experience does the successor have?

- $\quad$ More than 5 years

- 3-5 years

- $\quad$ Less than 3 years

- No successor available

\section{Accounting:}

- Are there enough members of staff with the appropriate qualifications?

- Yes

- No

- What is the frequency of billing?

- Daily

- Weekly

- $\quad<1$ Month

- 1 Month

- How often is the recovery of receivables performed?

- Weekly

- Monthly

- Monthly

- Is there a reliable costing of individual products?

- Yes

- No

- $\quad$ Are there periodic plans with sufficient detail?

- Monthly 
- Quarterly

- Yearly

- No plans

- Are these plans available to the bank?

- Yes

- No

- No plans

- Are deviations from plans being analyzed?

- Yes

- No

\section{Market incl. supplier and customer structure:}

- How intense is the competition?

- Very low

- Low

- Average

- High

- Very high

- How strong is the sensitivity to economic cycles?

- Very low

- Low

- Average

- High

- Very high

- Location of the enterprise:

- Not relevant

- Very good

- Good

- Average

- Bad

- Very bad

- How the company manage to sell their products?

- Very easily

- Easily

- Average

- Difficult

- Very difficult

- What is the development of demand?

- Strongly increasing 
- $\quad$ Increasing

- Stable

- Decreasing

- Strongly decreasing

- Is there a currency risk?

- No

- Low risk

- High risk

- Is there a dependency on the parent company?

- No

- Low dependency

- Strong dependency

- No parent company

\section{Supplier:}

- How many suppliers the company has?

$-\quad<50$

- $\quad 50-200$

- $>200$

- Not relevant

- How many of them are key suppliers?

- Number...

- What share of supply is the largest supplier?

- $\quad<10 \%$

- $10-25 \%$

- $26-40 \%$

- $\quad 41-60 \%$

- $>60 \%$

- How easy it would be to replace the largest supplier?

- Easy

- Average

- Difficult

\section{Customer:}

- How many customers the company has?

- $<10$

- $10-30$

- $>30$

- Not relevant 
- How many of them are key customers?

- Number...

- What share of turnover is the largest customer?

- $\quad<10 \%$

- $10-25 \%$

- $\quad 26-40 \%$

- $\quad 41-60 \%$

- $>60 \%$

- How easy it would be to replace the largest customer?

- Easy

- Average

- Difficult

\section{Qualification of employees / Technology:}

- How do you rate the qualification of employees?

- $\quad$ Scale from 1 (best) to 5 (worst)

- How the business invests in the renewal of technology, manufacturing equipment etc.?

- $\quad$ Scale from 1 (best) to 5 (worst)

- What is the capacity utilization rate?

- Full utilization

- Satisfactory

- Occasional fluctuations

- Frequent fluctuations

- Insufficient utilization

\section{Relationship with bank:}

- Have there been delays in repayment of the loan in the last 12 months?

- Often

- Few times

- Never

- New customer

- Have there been delays in repayment of the overdraft in the last 12 months?

- Often

- $\quad$ Few times

- Never

- New customer 
There are obviously quite big differences between systems in banks $A, B$ and $C$ in the range of required and filled-in information. In the case of Bank $A$, the range is very wide, several times larger than that of Bank $B$. At Bank $C$, the number of queries is between banks $A$ and $B$; however, the predefined structure of responses is different for individual questions (unlike Bank $A$, where the response scale is always the same or similar).

The Table 3 shows the categories (topics) as used on D, E and F rating systems from other sources (see above):

Table 3 Qualitative Indicators (Soft-Facts) - Part 2

\begin{tabular}{|c|c|c|c|c|c|}
\hline \multicolumn{2}{|l|}{ Rating D } & \multicolumn{2}{|l|}{ Rating E } & \multicolumn{2}{|l|}{ Rating F } \\
\hline $\begin{array}{l}\text { Management + } \\
\text { Business Strategy / } \\
\text { Planning }\end{array}$ & $23,0 \%$ & Management & $12,5 \%$ & Management & $24,0 \%$ \\
\hline \multirow[t]{2}{*}{ Audit quality } & $18,5 \%$ & Accounting & $25,0 \%$ & $\begin{array}{l}\text { Accounting, Planning } \\
\text { and Information } \\
\text { systems }\end{array}$ & $38,0 \%$ \\
\hline & & $\begin{array}{l}\text { Qualifications of } \\
\text { employees / } \\
\text { Technology } \\
\end{array}$ & $12,5 \%$ & Equipment + Systems & $17,0 \%$ \\
\hline $\begin{array}{l}\text { Market Position / } \\
\text { Share + Industry Risk }\end{array}$ & $31,0 \%$ & $\begin{array}{l}\text { Market and } \\
\text { Competition }\end{array}$ & $25,0 \%$ & $\begin{array}{l}\text { Market and market } \\
\text { position }\end{array}$ & $21,0 \%$ \\
\hline- & & - & & - & \\
\hline Ownership structure & $27,5 \%$ & Ownership structure & $12,5 \%$ & & \\
\hline & & $\begin{array}{l}\text { Economic situation + } \\
\text { Divergence from } \\
\text { planning }\end{array}$ & $12,5 \%$ & & \\
\hline
\end{tabular}

Note: The weights can be rounded.

Source: Author per data in "D": Belás, Cipovová (2011), "E": Kavan (2017) and "F":

Radojevic, Suknovic (2008)

For $D, E$ and $F$ rating systems, only a limited amount of data was available. Unfortunately, the authors of the relevant texts do not mention more specific questions or ways of evaluating soft-facts in their rating systems. However, the available data is useful for basic evaluation and conclusion.

If we compare all the mentioned rating systems and their main soft-facts indicators (topics), we can identify some similarities: all systems take (i) Management (or 
the closely related topic Strategy in case of bank B) and (ii) Market position of the company as important criteria, although with different weights (from 12,5\% to $30 \%$ for Management and from $15 \%$ to $31 \%$ for Market).

As the next most common criterion, three systems use (iii) Accounting, although in bank $F$ together with Planning and Information system (with the high weight of $38 \%$ ). Bank A uses a more general category Internal organisation, where Accounting is included. Rating system D includes the category Audit quality. Unfortunately, the data source (Belás, Cipovová (2011)) does not specify the extent to which this category deals with accounting, however, due to the structure of the other categories, this can be assumed with a high probability.

Among other soft - facts indicators, there are already substantially more variations, similar to the weight that each category has in the overall rating result. An interesting difference to mention is surely the category Relationship with the bank, which includes the duration as well as the quality of the collaboration between the bank and the customer (thus the rated company). Rating system $A$ takes this indicator as the most important one with the weight of $40 \%$ (rounded), system C attributes $10 \%$ weight to it, while all the others do not use this indicator at all (they use only problems in the relationship / previous collaboration with the customer as a warning signal, if available). Even the later approach can make good sense, considering the result of the rating process as a universal transferable number. The possibility to transfer the rating result can, but does not need to be relevant for the bank.

Another noteworthy difference between the rating systems is the use of the unique indicators in rating system B, concerning the divergence from company's planning in last three years and the company's business expectations including the bank's own view and opinion on these expectations.

\subsection{The Roles of Members of Staff in Making of the Rating}

In the context of soft - rating creation, it is worthwhile to briefly mention the collection and processing of the data in terms of competencies. These details are usually not mentioned directly in the manuals of the particular rating systems, their settings are rather governed by internal regulations of particular banks, or even just by habit.

Typically, two or three people participate in the making of the soft - facts rating (four- or six-eyes principle). The first one is a (i) representative of the bank (sometimes called account manager, relationship manager, or similar) who is in direct contact with the client. He / she acquires from the client both the data for the creation of hard - facts rating, and he / she also gets an idea about the functioning of the client's business during the negotiations. The information from the representative is therefore very valuable, on the other hand the representative is materially involved in the deal and thus wishes the client's rating to be as good as possible. There is a possible risk of conflicts of interest. 
Therefore, in most cases, the credit rating itself is the task of a second person, (ii) the analyst of the Risk management department. The analyst gets the information from the representative, conducts his own research (on web, in publicly accessible databases, from the news...) and then fills in the appropriate form (questionnaire) in the rating system. In some cases this role is entrusted to the (i) representative of the bank and the four-eyes principle is respected by the (iii) manager.

Finally, there is always (iii) a person with the authorization power (manager) who approves the final rating result. Mostly, this person is the chief of Risk management. Banks thus try to minimize potential conflicts of interest and also they prefer to make an "average" from the subjective views of more persons (members of staff) in making of the rating. The very fact of using soft - facts itself logically involves a subjective view, which the creators of the rating systems acknowledge. But the inclusion of more people's views and multiple sources of information is definitely desirable.

An interesting question is whether it is a good or not if the (ii) analyst visits the client personally. In the case of the (i) representative of the bank, personal visits are the rule, they are assumed and considered to be an important factor in creating an opinion. On the contrary, in the case of the (ii) analyst, such visits are considered to be rather exceptional. In the monitored cases, no requirements or limitations regarding personal visits to the client are defined in the rating system manuals. Decisions about them are thus left to the (iii) manager who may commission the analyst, or approve the analyst's own proposal respectively.

\section{Conclusions}

The result of the research shows that in all the compared rating tools, the qualitative factors (soft-facts) have lower weight (are less important) than the quantitative (hard - facts), but with the weight from $30 \%$ to $50 \%$ they surely are not negligible. In the case of the variable weight of both factors, the weight of the SF factor decreases as the size of the rated enterprise grows.

Two categories of qualitative indicators (soft - facts) are present in all considered rating systems: (i) Quality of company's Management and / or Strategy and (ii) Market, where the evaluated company operates. The weights vary from $12,5 \%$ to $30 \%$ for (i) Management and from $15 \%$ to $31 \%$ for (ii) Market.

Another regularly present qualitative indicator is (iii) Accounting or related indicators like Information system or Audit quality. In this case, the weighing range is wider, ranging from $15 \%$ to $38 \%$. This corresponds to a certain extent with the divergence of the definition and scope of this category in individual systems.

On the other hand, the use of the factor (iv) Relationship with the bank (or similar) is quite different across the surveyed rating systems. Here the range differs from very high weight $(40 \%)$ in one case to the most common situation, where the 
relationship with the bank is taken into account only in case of negative development as a risk factor.

Different is also the use of guidance questions for analysts when submitted to the system. In one case (bank $A$ ), there is an extensive catalog of questions with a standardized set of responses, ranked on a positive / neutral / negative / strongly negative scale, although not for every category / question all the answers are available. In other cases, (banks B and C), the number of questions is lower and each one has its specific variation of the predefined answers the analyst selects from.

The possible risk of conflicts of interest in data collection and making of the rating are solved by the four - eyes principle (two persons involved in making of the rating), or, mostly, by involving even three people. One of the engaged persons (representative of the bank) is systemically expected to have a subjective view of the client, while the others (analyst and manager) should maintain an independent view not prone to creating a conflict of interests.

\section{References}

Bank "A", "B" and "C" Rating Manuals (2011), (2004), (2008)

Belás, J. and Cipovová, E. (2011). Internal model of commercial bank as an instrument for measuring credit risk of the borrower in relation to financial performance (credit scoring and bankruptcy models). Journal of Competitiveness, 3(4), pp. $104-120$.

Crouhy, M., Galai, D. and Mark, R. (2001). Prototype risk rating system. Journal of Banking and Finance, 25(1), pp. 47-95.

Fracassi, C., Petry, S. and Tate, G. (2016). Does rating analyst subjectivity affect corporate debt pricing? Journal of Financial Economics, 120, pp. 514-538.

Grunert, J., Norden, L. and Weber, M. (2002). The role of non-financial factors in internal credit ratings. St. Louis: Federal Reserve Bank of St Louis. Available at: https://search. proquest.com/docview/1698225667? accountid=16531.

Guserl, R. (2014). Mit hard facts und guter kommunikation zu besseren ratings. Controlling \& Management Review, 58, pp. 78-83.

Hofmann, B. (2006). Die ausgestaltung des bankinternen ratingverfahrens als ansatzpunkt zur risikooptimierung. Zeitschrift Für Betriebswirtschaft, 76(6), pp. 651-680.

Kavan, P. (2017). Rizikové faktory ve výkazech pro rating. Diplomová práce Bankovní institut vysoká škola Praha, Katedra financí a ekonomie. Available at: https://is.bivs.cz/th/buykw/.

Morrow, B. E. (1998). The growing importance of qualitative factors in assigning financial ratings to insurers. The Interpreter, 70(5), pp. 26-29. Available at: https://search. proquest.com/docview/226070047?accountid=16531. 
Radojevic, G. and Suknovic, M. (2008). Fuzzy sets in financial analysis. Journal of Decision Systems, 17(2), pp. 211-223.

Svítil, M. (2017a). Banking rating systems for IRB: Comparison of three systems from German-speaking environment. 2017. Financial Assets and Investing, 8(2), pp. 61-74.

Svítil, M. (2017b). Comparison of banking rating systems. In European Financial systems 2017. Mezinárodní vědecká konference Brno 2017. Sborník European Financial systems 2017.

Svítil, M. (2018). Qualitative indicators (Soft-Facts) in internal rating systems. In European Financial systems 2018. Mezinárodní vědecká konference Brno 2018. Sborník European Financial systems 2018. 